\title{
ІННОВАЦІЙНА ЕКОНОМІКА
}

УДК 615.012(477):339.92 [ DOI: https://doi.org/10.31617/zt.knute.2021(118)08

JEL Classification: L52; L65; 014; 032

SALIKHOVA Olena

E-mail: salikhova_elena@ukr.net

ORCID: 0000-0002-7669-6601

HONCHARENKO Daria

E-mail:dp170292ddo@gmail.com

ORCID: 0000-0003-4937-2596
Doctor of Economics, Leading Researcher at the Modeling and Forecasting Department of Economic Development of the State Institution «NASU Institute of Economics and Forecasting"

26, Panas Myrnyi str., Kyiv, 01011, Ukraine

Chief Specialist at the Real Sector Development Department of the Main Department of the Real Economy Sector of the Directorate of Pricing Policy and Development of the Real Sector of Economy of the Ministry of Economy of Ukraine M. Hrushevsky str., 12/2, Kyiv, 01008, Ukraine

\section{ВИСОКОТЕХНОЛОГІЧНЕ ФАРМАЦЕВТИЧНЕ ВИРОБНИЦТВО В УКРАЇНІ: ВИКЛИКИ ЄВРОІНТЕГРАЦЇ̈}

Виявлено особливості політики Євросоюзу стосовно фармачевтики та зміни в підходах до ї̈ реалізачії в умовах пандемії COVID-19. Проаналізовано ініиіативи й юридично унормовані заходи щодо фармацевтичної діяльності в Україні. Сформульовано рекомендації з удосконалення політики та розвитку високотехнологічного фармачевтичного виробництва; визначено стратегічні пріоритети й ключові засади їх досягнення з урахуванням досвіду та сучасних настанов $Є C$.

Ключові слова: євроінтеграція, фармацевтика, промислова політика, стратегія, лікарські засоби, медичні вироби, високі технології, інновації.

Постановка проблеми. Верховна Рада України в перші роки незалежності вказала на самоідентифікацію України як європейської держави, заклавши фундамент для ухвалення низки визначальних нормативно-правових актів, що закріпили євроінтеграційний вектор розвитку економіки країни, зокрема Угоди про асоціацію між Україною та ЄС, що обумовило трансформаційні процеси фармацевтичної індустрії.

Нові виклики та загрози економіці України через глобальну пандемію COVID-19 спонукають до пошуку дієвих механізмів забезпечення

(C) Salikhova O., Honcharenko D., 2021 
стабільності фармацевтичної діяльності, системи охорони здоров'я, економіки й національної безпеки. Щоб фармацевтика України мала максимальні зиски від процесу євроінтеграції (посилення технологічного потенціалу, збільшення ефективності виробництва та конкурентоспроможності продукції, налагодження стійких зв'язків з європейськими виробниками) і вийшла на ринок $Є С$, розвиток галузі має відбуватися 3 урахуванням як європейських настанов, так і національних інтересів.

Аналіз останніх досліджень і публікацій. У дослідженнях вітчизняних науковців розглянуто питання стратегічних орієнтирів розвитку фармацевтики України [1; 2]; проблеми та перспективи курсу на членство в СС і можливі наслідки для галузей промисловості, зокрема фармацевтики [3; 4]; нюанси правового забезпечення імплементації законодавства Євросоюзу щодо обігу ліків [5]; шляхи формування інноваційної політики у сфері охорони здоров'я в контексті європейської інтеграції, а також наслідки євроінтеграційних процесів для вітчизняного фармацевтичного виробництва [6], сучасні політичні, економічні та соціальні виклики пандемії COVID-19 [7] і відповіді на них [8]. Водночас механізми розбудови фармацевтики з опорою на національні інноваційні надбання та перетворення галузі на рушій економічного зростання в Свросоюзі залишаються недостатньо висвітленими, а роль керівництва СС у цьому процесі - не до кінця вивченою, тож ця тема є дискусійною, що негативно позначається на ухваленні політичних рішень 3 нагальних питань розвитку фармацевтики України в умовах євроінтеграції через наявні переконання, що «усе повинен вирішувати ринок».

Метою статті $\epsilon$ окреслення та обгрунтування необхідних заходів політики розвитку фармацевтики України в умовах євроінтеграції. Задля цього варто вирішити три завдання: виявити ключові засади політики Свросоюзу щодо розвитку галузі та їхні зміни в умовах пандемії COVID-19; оцінити ініціативи та юридично унормовані заходи політики щодо фармацевтичної діяльності в Україні; обгрунтувати рекомендації стосовно засад розвитку високотехнологічного фармацевтичного виробництва (ВТФВ) в Україні з опорою на національні інноваційні надбання, визначити стратегічні пріоритети та заходи з урахуванням останніх змін у політиці ЄС.

Матеріали та методи. Теоретико-методологічною основою для написання статті стали праці вітчизняних і закордонних науковців з формування та реалізації політики щодо фармацевтичної діяльності, нормативно-правові документи ЄС та України. Дослідження проводилось 3 використанням методів теоретичного узагальнення, порівняльного аналізу та синтезу, що дало змогу виявити засади політики ЄС щодо розвитку галузі; оцінити трансформацію нормативно-правового підгрунтя фармацевтичної діяльності в Україні в умовах євроінтеграції та сформулювати рекомендації щодо його удосконалення. 
Результати дослідження. Ключові засади політики керівництва Свросоюзу з розвитку фармацевтики та їхніх змін в умовах пандемії $\boldsymbol{C O V I D - 1 9 . ~ Д л я ~ к е р і в н и ц т в а ~} \mathrm{CC}$ фармацевтична промисловість $є$ стратегічним пріоритетом. Ще у 1994 р. у Повідомленні Сврокомісії про засади промислової політики у фармацевтичному секторі СС [9] зазначено, що ця галузь належить до найефективніших високотехнологічних секторів Свропи; створює велику кількість робочих місць в економіці; грає ключову роль у системі охорони здоров'я, а також у системі соціального забезпечення (можливість фінансування споживання фармацевтичних продуктів має прямий вплив на національні бюджети соціального забезпечення). Сврокомісією визначено, що, оскільки фармацевтичний сектор $є$ важливим активом економіки (як 3 огляду на зростання, так і зайнятості), необхідною є підтримка іiі базової економічної потужності та конкурентоспроможності. Отже, розвиток галузі має відбуватися через компліментарні заходи низки політик: політики щодо громадської охорони здоров'я та соціального забезпечення, 3 одного боку, і підтримки промислового розвитку й зайнятості - 3 іншого. В основу розробки реалістичної промислової політики та забезпечення робочих місць у фармацевтичному секторі має бути покладений діалог між державними службовцями, роботодавцями, профспілками та групами пацієнтів. Керівництво СС звертало увагу країн-членів на те, що кількість вироблених галуззю лікарських засобів (ЛЗ) не може бути статистично пов'язана зі здоров'ям населення через наявність специфічних захворювань; значну роль у розвитку галузі мають відігравати створення інноваційних Л3, виходячи 3 нагальних потреб суспільства та нових викликів. Країнам-членам рекомендовано враховувати ці аспекти за формування відповідних політик національного рівня.

Завдяки низці офіційних документів СС, ухвалених у 1990-х рр., після дебатів з цього питання закладено фундамент сучасної європейської промислової політики для фармацевтичного сектору (industrial policy for the pharmaceutical sector) $[10 ; 11]$. У Резолюції Ради від 23 квітня 1996 р., спрямованій на реалізацію основних принципів промислової політики у фармацевтичному секторі СС [12], визначених у повідомленні 1994 р. [9], керівництво СС зверталось до держав-членів щодо важливості приділити увагу зв'язку між політикою контролю витрат на охорону здоров'я та заходами із забезпечення конкурентоспроможності національної фармацевтичної промисловості. До того ж промислова політика щодо фармацевтики має однаковою мірою враховувати законні інтереси всіх економічних агентів: виробників, що здійснюють дослідження та розробки (ДіР); виробників непатентованих ліків, фітофармацевтичних препаратів, лікарських рослин і гомеопатичних препаратів; комерсантів; фармацевтів. У Резолюції обгрунтовано, що через посилення конкуренції та збільшення витрат на ДіР європейський фармацевтичний сектор знаходиться під загрозою падіння й 
відставання від своїх основних конкурентів (передусім США); отже, необхідно запровадити заходи політики розвитку галузі, що сприятимуть технологічним інноваціям і промисловим інвестиціям, які $\epsilon$ важливими факторами прогресу в інтересах пацієнта, суспільства та економіки загалом.

Для країн-членів керівництво ЄС визначило засади реалістичної промислової політики, зокрема: направити європейські ДіР у бік реальних інновацій (real innovation) за принципом більшої віддачі на вкладені гроші (more bang for your buck); скоротити тривалість і вартість необхідних процедур затвердження нових ЛЗ, не піддаючи ризику громадське здоров'я; зменшити фрагментацію ДіР і виробництва; а також покласти край нестримному використанню реклами ЛЗ.

Визначено базові принциии промислової політики щзодо фармацзевтики, а саме:

- заохочення інновацій через конкурентний ринок і відповідні зміни нормативно-правової бази;

- захист нових ЛЗ правами інтелектуальної власності як в $\mathrm{CC}$, так і у третіх країнах;

- забезпечення доступності ЛЗ для оптимального захисту здоров’я громадян Свропи;

- просування досліджень інноваційних методів лікування, що особливо важливо з погляду громадської охорони здоров'я, і заохочення досліджень рідкісних захворювань і розробки відповідних ЛЗ.

У 2000-х рр. Свропа залишається світовим лідером у фармацевтичному секторі, фармацевтика демонструє відмінні загальні показники. Водночас через фінансово-економічну кризу 2009 р. сектор стикнувся 3 багатьма викликами та проблемами ${ }^{1}$, які уповільнили розвиток і погіршили перспективи. Це спонукало керівництво СС шукати нові шляхи забезпечення конкурентоспроможності та стійкості фармацевтики. У 2014 р. ухвалено документ «Фармацевтична промисловість: стратегічний сектор європейської економіки» [13]. Пріоритети, що визначені документом, реалізовувалися протягом 2014-2020 pp. у рамках конкретних фінансових ініціатив у галузі охорони здоров'я, зокрема й у рамках Програми охорони здоров'я, Свропейської дослідницької програми «Horizon 2020» та Структурних фондів СС на 2014-2020 pp.

${ }^{1}$ Серед проблем, що загострилися у другій декаді 2000-х рр., йдеться про: більш жорсткі державні бюджети як наслідок повільних темпів зростання в СС, який постраждав від фінансово-економічної кризи 2009 р., і відтак скорочення внесків на соціальне страхування; короткострокова спрямованість заходів, що вживалися урядами для подолання фінансових обмежень бюджетів громадської охорони здоров'я у відповідь на бюджетну кризу, яка затягнулася після 2009 р. у деяких державах - членах $\mathrm{CC}$; відмінності в заходах політики (зокрема щодо ціноутворення / відшкодування вартості ліків у державах-членах) і перетікання ефекту жорсткої економії національних витрат від однієї держави-члена до іншої, незалежно від соціально-економічних умов; глобалізація і поява нових конкурентів, які націлені на біологічні науки як на майбутні рушії зростання фармацевтики тощо. 
Тож Ініціатива зі створення інноваційних медикаментів (Innovative Medicines Initiative - IMI) стала одним з флагманів досліджень у галузі охорони здоров'я у рамках Horizon'2020, що реалізується на засадах державно-приватного партнерства в галузі наук про життя між СС та європейською фармацевтичною промисловістю. IMI орієнтована на прискорення розробки більш якісних і безпечних ліків; підвищення успішності клінічних випробувань нових ліків і вакцин; прискорення ранніх стадій розробки ліків; створення нових біологічних маркерів для діагностики захворювань й оцінки лікування. 32008 по 2013 р. загальний бюджет IMI становив близько 2 млрд євро. У 2014-2024 pp. його бюджет досягне 3.3 млрд євро, половина 3 яких надійде від Horizon'2020 [14]. У відповідь на спалах COVID-19 Сврокомісія у рамках Horizon'2020 асигнувала IMI 45 млн євро за прискореною процедурою.

Як показало дослідження [15], СС не лише підтримує ДіР наукових установ і університетів, а й науково-технологічну, інноваційну та інвестиційну діяльність приватного бізнесу ${ }^{2}$. Виробники фармацевтичної продукції у країнах ЄС отримують допомогу здебільшого завдяки регіональним і горизонтальним механізмам. Така допомога надається в контексті визначених технологічних, інноваційних і промислових пріоритетів як загально європейського, так і національного рівня.

Ще одним важливим механізмом підтримки фармацевтичних виробництв $є$ регіональна інвестиційна допомога ${ }^{3}$. Вона зазвичай надається для початкових інвестицій, зокрема інвестицій на користь нової економічної діяльності (капіталовкладення в матеріальні та нематеріальні активи, пов'язані з розширенням можливостей наявного підприємства, диверсифікацією його продукції або змінами загального виробничого процесу, а також в активи, пов'язані зі створенням нового підприємства або диверсифікацією його діяльності).

Зазначені заходи політики ЄС стимулюють розвиток фармацевтики, сприяючи світовому лідерству галузі. У звіті Національного наукового фонду США у 2018 р. за індикатором «Додана вартість» фармацевтичне виробництво ЄС посіло перше місце - 183542 млн дол. США [16].

Проте, попри міцні позиції європейських виробників на світовому ринку, пандемія COVID-19 вплинула на галузь сильніше, ніж будь-який інший економічний шок в історії $\mathrm{EC}$, спричинивши

2 Згідно з регламентами ЄС, державна допомога на ДіР та інновації спрямовується для відшкодування суб'єктам господарювання витрат на реалізацію проєктів 3 фундаментальних і промислових досліджень (industrial research), експериментальних розробок, а також на організацію досліджень і поширення знань. Допомога може покривати вартість обладнання; витрати на будівлі та землю, які використовуються для реалізації проєкту; витрати на патенти, консультаційні послуги тощо.

3 Зразком підтримки технологічного розвитку фармацевтичних виробників на регіональному рівні є Баварська програма 3 просування проєктів досліджень і розробок у галузі біотехнологій та генної інженерії (Forschungsprogramm «Bio- und Gentechnologie»-BayBIO). 
перебої у постачаннях і заблокувавши ланцюжки створення доданої вартості. Це сприяло усвідомленню урядами країн СС необхідності усунення залежності фармацевтичного виробництва від зовнішніх торговельних партнерів, посилення інноваційного потенціалу, диверсифікації виробництва і постачання, виготовлення стратегічних запасів, інвестування у розширення номенклатури продукції наявних компаній, створення нових підприємств та решорингу (перенесенню) виробництв стратегічних товарів на територію Свропи.

Аби уникнути дефіциту під час спалаху COVID-19 у квітні 2020 р., Єврокомісія надала Рекомендації з оптимального та раціонального постачання ліків [17], зазначивши, що поточна криза вимагає значного збільшення фармацевтичного виробництва, а також реорганізації ланцюжків постачання й виробничих ліній і використання наявних запасів фармацевтичних інгредієнтів для максимально швидкого збільшення випуску. 3 огляду на це країнам-членам рекомендувалося підтримати промисловість у частині нарощування виробничих потужностей через податкові стимули та механізми державної допомоги.

Подальшим кроком стало формування (на засадах соціального діалогу) цілісної, орієнтованої на пацієнта й на майбутнє нової «Фармацевтичної стратегії для Свропи», яку ухвалено в листопаді 2020 р. [18]. Основні цілі стратегії - підтримати конкурентоспроможність, інноваційний потенціал і стійкість фармацевтичної промисловості ЄС. У травні 2021 р. керівництво ЄС представило переглянуту з урахуванням обставин пандемії COVID-19 «Нову промислову стратегію для Європи» [19], серед завдань якої - забезпечення стійкості промисловості та зменшення залежності промислових екосистем, 3-поміж яких промислова екосистема «Охорона здоров’я», що охоплює фармацевтичні та медичні продукти, засоби індивідуального захисту, медичні послуги. Метою є сприяння взаємодії учасників і допомога політикам та інвесторам визначити найважливіших гравців у кожній екосистемі під час підготовки національних і регіональних планів відновлення та інвестиційних проєктів у сфері фармацевтики й медицини. Серед пріоритетів: диверсифіковане міжнародне партнерство (забезпечення сприятливих умов, аби торгівля та інвестиції продовжували відігравати ключову роль у зміцненні економічної стійкості ЄС); створення промислових альянсів (запуск платформ, що прискорять діяльність у промислових екосистемах, допоможуть залучити приватних інвесторів, інтегрують у спільні проєкти стартапи та МСП); моніторинг стратегічних залежностей (виявлення стратегічних залежностей СС від постачання 3 іноземних джерел продуктів в уразливих промислових екосистемах).

Настанови як фармацевтичної, так і промислової стратегії орієнтують уряди країн-членів до запровадження механізмів політики усунення наслідків стратегії делокалізації (delocalisation strategies) та зменшення залежності від офшорного виробництва як активних 
фармацевтичних інгредієнтів (АФІ), так і готових ЛЗ і медичних виробів (МВ) через: розширення «продуктового портфеля» наявних компаній, створення нових підприємств «з нуля» та/або решорингу (reshoring) виробничих потужностей фармацевтичного виробництва на територію Євросоюзу або інших європейських країн. Ці настанови вже реалізуються внаслідок механізму державної допомоги. Під час кризи COVID-19 Єврокомісія схвалила численні заходи, сумісні з внутрішнім ринком, зокрема: допомогу на відшкодування збитків, викликаних надзвичайними подіями (Articles 107 (2) b TFEU); допомогу в усуненні серйозних порушень в економіці держави-члена (Articles 107 (3) b TFEU); допомогу для сприяння розвитку певних секторів або галузей економіки (Articles 107 (3) c TFEU), через які держави-члени надають допомогу як компаніям фармацевтичної індустрії, так і суміжних галузей. Водночас Керівництво ЄС запровадило механізм інвестиційної допомоги для виробництва продуктів, що мають відношення до COVID-194. Інтенсивність допомоги становила до $80 \%$ витрат на проєкт. Низка країн отримала згоду Єврокомісії на таку допомогу, серед них: Ірландія, Німеччина, Польща, Угорщина, Чехія та інші. Країни Центральної та Східної Свропи у реалізації механізмів підтримки інвестиційно-інноваційних проєктів фармацевтичних компаній спираються не лише на асигнування 3 бюджету, але й отримують значні кошти з європейських фондів у рамках національної реалізації політики згуртування ЄС у галузі досліджень і розробок та інновацій.

Відбулися й деякі зміни у системі публічних закупівель ЄС. Австрійські вчені зазначають, що пандемія COVID-19 показала гнучкість законодавчої бази СС щодо закупівель у кризових ситуаціях [20]. Деякі новели у правовому забезпеченні, що впливають на фармацевтичну діяльність, запроваджені у Німеччині, Франції та інших європейських країнах.

Ініціативи та юридично унормовані заходи політики розвитку фармацевтики України. Для імплементації законодавства ЄC у нормативно-правову і нормативно-технічну базу України та запровадження нових заходів регулювання діяльності, пов'язаної 3 фармацевтичною промисловістю, в Україні ухвалено низку підзаконних актів, наказів МO3, нормативно-технічних документів, запроваджено програми розвитку. Водночас В. Хоменко зазначає, що за роки незалежності в Україні виникли серйозні проблеми в держаному управлінні, втрачено «вертикаль» в управлінні, що

${ }^{4}$ Продуктами, що мають відношення до COVID-19, визначено: Л3 (включаючи вакцини) та їхні проміжні продукти, АФІ і сировину; медичні прилади, медичне обладнання (включаючи апарати ШВЛ, захисний одяг і обладнання, а також діагностичні інструменти) і необхідну сировину; дезінфікуючі засоби та їхні проміжні продукти, хімічну сировину, необхідну для їхнього виробництва; інструменти збору / обробки даних. 
негативно позначилось на організації фармацевтичної діяльності та забезпеченні населення ліками. Однією $з$ основних причин такого стану $є$ відсутність системного підходу до обгрунтування принципів і механізмів державного управління розвитком галузі [21].

Ретроспективний аналіз ухвалених нормативно-правових актів (НПА) показав, що з метою боротьби із соціально значущими захворюваннями в Україні урядом 3 початку 2000-х рр. прийнято та реалізовано понад 10 програм, серед яких: Міжгалузева комплексна програма «Здоров'я нації» (2002-2011 рр.), Державна програма запобігання та лікування серцево-судинних і судинно-мозкових захворювань (2006-2010рр.), Загальнодержавна програма імунопрофілактики та захисту населення від інфекційних хвороб (2009-2015 рр.) тощо. Цими програмами передбачено щорічну закупівлю за державні кошти ЛЗ та МВ, але, як зазначали 10 років тому фахівці галузі, «переважна кількість державних коштів витрачається на закупівлю імпортних ЛЗ і тільки незначна кількість - на закупівлю препаратів, що виробляються фармацевтичними підприємствами України» [22].

Ще у 2005 р. на VI Національному з’їзді фармацевтів України прийнято Концеецію розвитку фармацевтичної галузі Украӥни (далі Концепція фармацевтів-2005), яка стала певною точкою відліку для галузі [23]. У документі прописано, що «за умов сучасних трансформаційних процесів, що відбуваються у світовій і вітчизняній фармації, особливого значення набуває формування національної лікарськой політики». Щодо розвитку фармацевтичного виробництва у Концепції вказано на необхідність реалізації низки пріоритетних заходів, пов'язаних 3 державним замовленням на виробництво й постачання основних Л3; налагодження вітчизняного виробництва вакцин, інших медичних імунобіологічних і решти препаратів нового покоління; освоєння нових напрямів у створенні ЛЗ: генної інженерії, молекулярної біології тощо.

Низку з поданих рекомендацій включено до проєкту Концепції Державної иільової програми створення вітчизняних імунобіологічних препаратів «Українська вакцина» на 2011-2015 р. [24], який у березні 2010 р. МО3 виніс на публічне обговорення, обгрунтовуючи необхідність ухвалення цього НПА, як-от:

- в Україні не існує жодного потужного сучасного біотехнологічного центру, здатного оперативно вирішувати нагальні потреби медицини та фармакології;

- у країні фактично відсутня науково-лабораторна база для розробки вітчизняних сучасних вакцин, генних діагностикумів, антибіотиків нового покоління тощо.

Єдиний можливий вихід з цієї ситуації - визначення термінової організації вітчизняного виробництва імунобіологічних препаратів, що масово використовуються у державі. Проєкт Концепції розроблено на виконання рішення РНБОУ від 18 січня 2006 р. «Про заходи щодо 
підвищення ефективності боротьби 3 небезпечними інфекційними хворобами», затвердженого Указом Президента України від 14.02.2006 р. № 132/2006; а також рішення РНБОУ від 27 лютого 2009 р. «Про біологічну безпеку України», затвердженого Указом Президента України від 06.04.2009 р. № 220/2009. Однак, попри важливість та актуальність, програма «Українська вакцина», ініційована у 2010 р., так і не запущена.

У 2011 р. МO3 представив інший документ - проєкт Концепції Державної цільової програми «Розвиток імпортозамінних виробництв в Україні та заміщення імпортованих лікарських засобів вітчизняними, зокрема біотехнологічними препаратами та вакцинами на 2011-2021 роки» [22] (далі - Програма імпортозаміщення), яка передбачала конкретні кроки, пов'язані з розробкою та виробництвом нових ЛЗ, a саме: забезпечення повного циклу виробництва життєво важливих Л3 в Україні: від синтезу (біосинтезу) субстанції до готової лікарської форми там, де це можливо, і зменшення залежності від постачань імпортних субстанцій; фінансування з держбюджету закупівлі ліцензій на виробництво інноваційних ЛЗ 3 подальшим освоєнням їхнього виробництва на провідних фармацевтичних підприємствах України; а також запровадження преференцій за виробництва та публічних закупівель.

Попри актуальність і вагомі аргументи щодо необхідності такої програми та конкретні пропозиції щодо їі реалізації, низка асоціацій, що діють в Україні, зокрема Європейська Бізнес Асоціація (СБА), звернулися до уряду 3 вимогою не допустити ухвалення Програми імпортозаміщення, вказуючи на те, що Україна завершує переговори про створення зони вільної торгівлі, взявши на себе певні зобов'язання, а тому СБА «звертає увагу на ризик виконання нерівних конкурентних умов для вітчизняних та іноземних виробників в Україні, у разі якщо проєкт Концепції буде схвалено урядом. Крім того, з 2008 р. Україна $\epsilon$ повноправним членом СОТ, i проєкт Концепції щодо «імпортозаміщення», який запропоновано, може поставити під сумнів виконання країною принципів і норм СОТ через можливість дискримінації імпортованих товарів» [25]. Отже, цей «аргумент», на жаль, виявився вагомішим за проблеми системи охорони здоров'я, вітчизняних виробників і загрози національній безпеці України. Під тиском лобістів іноземних фармацевтичних компаній Програму імпортозаміщення не прийнято.

Через п’ять років потому МО3 знов спробував запустити цю програму. На урядовому порталі у 2016 р. розміщено повідомлення: «MO3 із залученням представників громадськості, професійного середовища та фармацевтичного ринку розпочинає процес розробки Концепції державної програми розвитку імпортозаміщення в Україні, спрямованої на збільшення частки ЛЗ вітчизняного виробництва на медичному ринку нашої країни, підтримки вітчизняного виробника, розвитку імпортозамінних виробництв ЛЗ i виробів медичного 
призначення [26]. Але і з другої спроби Програму імпортозаміщення не запущено.

У 2010 р. за поданням МО3 прийнято Концепцію програми створення та проведення доклінічних випробувань вітчизняних лікарських засобів [27], де вказувалося, що «в Україні не створено систему розроблення та цільового виготовлення лікарських субстанцій, вакцин, антибіотиків нового покоління, сучасних генних діагностикумів, тестсистем та інших Л3, а також спеціалізовані лабораторії з відповідним науково-технологічним обладнанням для проведення доклінічного випробування нових хімічних сполук». У червні 2011 р. (через місяць після ухвалення) оприлюднено Постанову КМУ «Про затвердження Державної цільової науково-технічної програми розроблення новітніх технологій створення вітчизняних лікарських засобів для забезпечення охорони здоров'я людини та задоволення потреб ветеринарної медицини на 2011-2015 роки» № 725 від 22.06.2011 p. [28] із запланованим обсягом фінансування 2.7 млрд грн., зокрема за рахунок державного бюджету - 1.2 млрд грн., 3 яких до 300 млн грн. мали спрямувати на дослідження, пов'язані з розробленням молекулярних і клітинних технологій створення вітчизняних Л3, біологічно активних речовин. Проте вже за результатами першого року реалізації програми стало очевидно, що вона не є пріоритетом для уряду - іiі профінансовано лише обсягом 7.3 млн грн. [29]. Проіснувавши два роки, Концепція й програма втратили чинність на підставі Постанови КМУ № 71 від 05.03.2014 p.

Сдиним документом, що визначав в Україні політику щодо розвитку галузі, був Наказ МО3 № 769 13.09.2010 р., яким схвалено Концепцію розвитку фармацевтичного сектору галузі охорони здоров'я України на 2011-2020 pp. (діяла у редакції Наказу МО3 від 27.03.2013 р. № 242) [30] (далі - Концепція розвитку фармацевтики). Цей документ визначає перспективні напрями та завдання фармацевтичної галузі й спрямований на створення відповідної нормативноправової бази, що регулює фармацевтичну діяльність, розробку національної політики у фармацевтичній сфері. Серед поставлених завдань:

- стимулювання розробки та виробництва основних ЛЗ, підтримка експорту Л3, зокрема через відпрацювання додаткових механізмів фінансування вітчизняних розробок;

- розроблення оптимальної стратегії імпортозаміщення ЛЗ та передбачення 价 виконання в загальнодержавній цільовій програмі розвитку промисловості на період до 2020 р.;

- запровадження нових преференцій для вітчизняних виробників ЛЗ у разі освоєння виробництва конкурентоспроможних інноваційних та імпортозамінних генеричних Л3, а також за державної закупівлі вітчизняних ЛЗ;

- здійснення першочергових державних закупівель ЛЗ вітчизняного виробництва, що розроблені за бюджетні кошти; 
- надання вітчизняним виробничим підприємствам, що здійснюють виробництво ЛЗ, преференцій у системі закупівлі ЛЗ за державні кошти та забезпечення режиму найбільшого сприяння з боку держави фармацевтичним підприємствам, що відповідають установленим вимогам.

У Плані заходів, прийнятому на виконання Концепції розвитку фармацевтики, [31] 380 пунктів немає жодного, що передбачав би державне сприяння реалізації проєктів бізнесу щодо розробки нових ЛЗ i запуску їх у виробництво, надання преференцій, використання системи публічних закупівель в інтересах національних виробників. Отже, завдання Концепції щодо розвитку фармацевтики залишилися загалом на папері.

Погіршення стану економіки через COVID-19 спонукало КМУ ухвалити документ щодо стимулювання економіки, де серед ключових видів діяльності визначено виробництво основних фармацевтичних продуктів і препаратів [32]. 3-поміж короткострокових ініціатив серед заходів зазначено «фінансування наукових досліджень, розробок та інноваційних проєктів, що спрямовані на запобігання виникненню та поширенню COVID-19» із запланованим обсягом асигнувань на 2020 р. у 500 тис. грн., або 17.58 тис. дол. США (за офіційним курсом НБУ на 01.11.2020). 3 огляду на те, що у 2011 р. у рамках Програми створення вітчизняних ЛЗ обгрунтована необхідність спрямування на дослідження, пов'язані з розробленням молекулярних і клітинних технологій створення вітчизняних ЛЗ, біологічно активних речовин, щонайменше 300 млн грн., або 9.9 млн дол. США (за офіційним курсом НБУ на 01.11.2020), запланованих у 2020 р. асигнувань на ДіР та інновації для запобігання виникненню та поширенню COVID-19 явно недостатньо.

У грудні 2020 р. МО3 виставив на обговорення черговий проєкт НПА - Концепцію Державної цільової програми створення та розвитку внутрішнього виробництва високоякісних лікарських засобів для профілактики й лікування особливо небезпечних інфекційних та інших хвороб для забезпечення державних потреб України на 2021-2026 рр. [33], що, по суті, є аналогом розглянутої програми «Українська вакцина» 2010 р. У пояснювальній записці проєкту НПА профільне міністерство вказує: «Через втрату власного виробництва імунобіологічних препаратів і практично повну залежність держави від імпортних поставок таких препаратів і враховуючи загострення епідемічної ситуації в Україні, постає питання національної безпеки загалом». Отже, через 10 років від запуску Концепції розвитку фармацевтики констатовано не створення, а втрату власного виробництва. На засіданні Президії НАН України, присвяченому участі вчених академії у протидії COVID-19, міністр охорони здоров'я України у своєму виступі зазначив, що керівництво держави має намір відновити в Україні власне фармацевтичне виробництво імунобіологічних препаратів, підкресливши, що пріоритетом $\epsilon$ 
формування фармацевтичної незалежності нашої держави, яке має розпочатися саме з виробництва власних імунобіологічних препаратів [34]. Попри ці декларації, документ станом на 01.07.2021 р. не ухвалено.

Попри низку ініціатив MO3 у частині розробки проєктів НПА щодо цілеспрямованих заходів з розвитку фармацевтичного виробництва та зменшення залежності від імпорту, а також ухвалені НПА, які є підгрунтям для розбудови виробництва ЛЗ та МВ в Україні, Концепція розвитку фармацевтики до 2020 р. була фактично єдиною, що визначала національну політику щодо фармацевтичної діяльності. Сьогодні такий документ у країні відсутній.

Прийнята Національна економічна стратегія на період до 2030 р. серед цілей має «Забезпечення високого рівня здоров’я та високих показників тривалості життя й тривалості здорового життя». Одним зі шляхів їі досягнення, як зазначено в документі, є «реалізація фармацевтичної політики та забезпечення доступу до якісних, ефективних i безпечних ліків», зокрема розвиток національного фармацевтичного виробництва [35], що передбачає реалізацію завдань, як-от: підтримка розвитку виробництва критично необхідної продукції; запровадження кредитного стимулювання фармацевтичних компаній; зменшення податкового та митного навантаження на обладнання, комплектувальні вироби до нього та інші матеріали для виробництва інноваційних ЛЗ, вакцин, медичної техніки; залучення міжнародного фінансування для розвитку фармацевтичного виробництва в Україні.

Зазначений стратегічний урядовий документ, як і Концепція фармацевтів 2002 р., підтверджує, що в Україні є лише фармацевтична (лікарська) політика, до того ж не реалізується промислова політика щодо фармацевтики, як в ЄС. Фармацевтична політика поєднує розробку, надання та використання ліків у системі охорони здоров'я та стосується дій уряду щодо забезпечення населення ЛЗ у контексті державної політики в галузі охорони здоров'я; тоді як промислова політика щодо фармацевтики як активу національної економіки, з огляду на загальні принципи промислової політики $\mathrm{CC}$, має дещо інші цілі, а саме: спрямованість на підвищення конкурентоспроможності галузі, перетворення іiі на рушій сталого зростання та зайнятості.

Вдосконалення засад розвитку фармацевтики України. У ході дослідження визначено, що ВТФВ України в умовах євроінтеграції вимагає доповнення заходів фармацевтичної політики заходами промислової політики зі спрямуванням останньої на заохочення випуску не лише готових Л3 і МВ, а також хімічних і біологічних проміжних товарів (передусім АФІ) на базі ендогенних інновацій та продуктів суміжних виробництв. 
Як показує досвід ЄС, розвиток ВТФВ України вимагає комплементарних дій і запровадження механізмів низки політик (поряд 3 політикою щодо охорони здоров'я та промислової політики), як-от:

фінансова (запровадження стимулів у вигляді субсидій на створення / розширення виробництв, податкових пільг, позик);

у сфері наукової, науково-технічної та інноваційної діяльності (запровадження стимулів у вигляді субсидій на ДіР та інновації бізнесу, розвиток дослідницької інфраструктури);

торговельна (ініціювання перегляду окремих положень Угоди COT про субсидії та компенсаційні заходи, Угоди СОТ про державні закупівлі, Угоди про пов’язані з торгівлею інвестиційні заходи задля отримання тимчасової можливості запроваджувати заходи в інтересах прискореного розвитку національних виробників ЛЗ, МВ, проміжних i супутніх товарів 3 метою зменшення залежності фармацевтичного виробництва та загроз національній безпеці $)^{5}$;

y сфері публічних закупівель (внесення змін щодо пріоритезації національних виробників);

освітня (внесення змін у навчальні курси з метою підготовки фахівців для фармацевтичної науки та виробництва);

екологічна (запровадження механізмів державної допомоги на заходи щодо скорочення відходів, повторного використання та утилізації відходів фармацевтичного виробництва);

інформаційна (запровадження заходів з популяризації української фармацевтики та іiї виробів).

Фармацевтика має бути визначена стратегічною галуззю 3 погляду пріоритетів національного економічного розвитку. Це вимагає внесення змін у Національну економічну стратегію на період до 2030 р., а також розробки Стратегї розвитку ВТФВ України (далі - Стратегія) [36], що становитиме набір цілей, інструментів і заходів, чітко узгоджених між собою, а також з економічними пріоритетами держави, серед яких європейська економічна інтеграція. Питання необхідності розробки стратегічного документа, що визначатиме розвиток фармацевтики в Україні, неодноразово підіймалося як вітчизняними вченими, так і галузевими спеціалістами. За останні 10 років в Україні накопичено чимало напрацювань у цій частині, але їхньою спільною рисою $є$ фокусування передусім на виробництво ЛЗ і МВ (у таблиці подано таксономію проєктів та ухвалених НПА, що визначають фармацевтичну політику).

5 Дослідження досвіду Німеччині та Китаю показали, що використання механізмів, які сьогодні заборонені світовою системою регулювання, уможливило прискорене зростання фармацевтичного виробництва [37; 38]. 


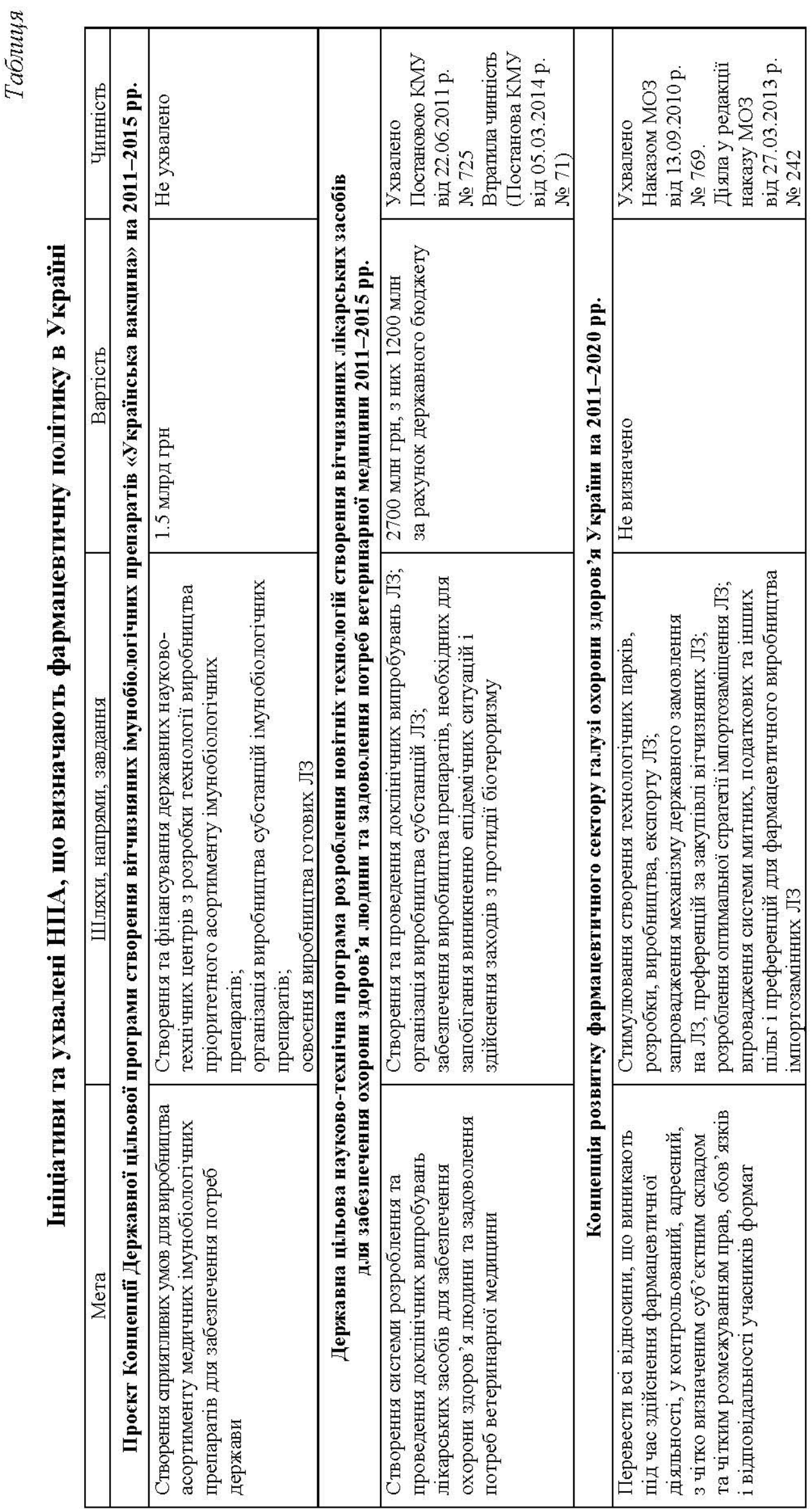




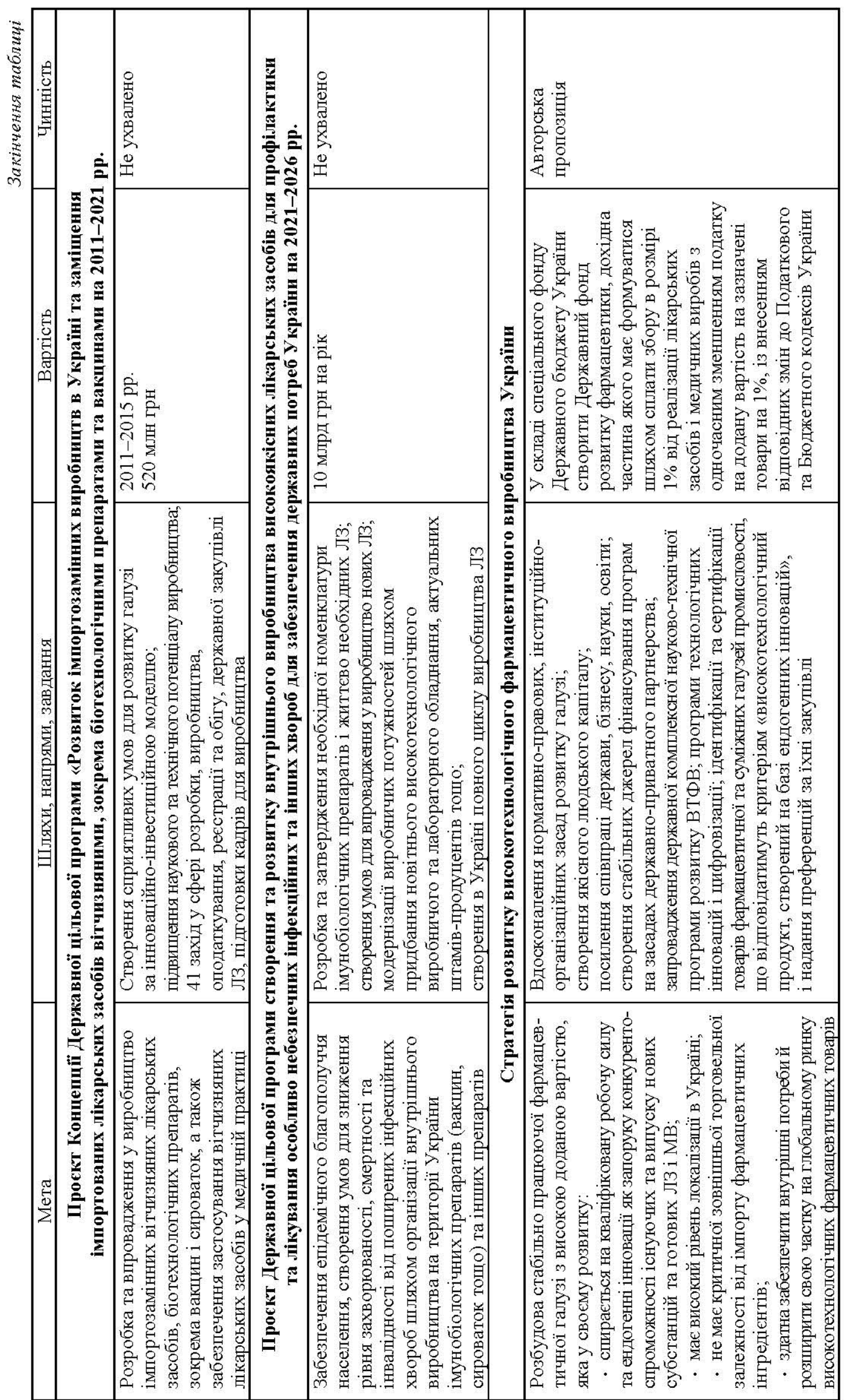


У політиці розвитку ВТФВ України варто спиратися на комплексний підхід 6 .

3 огляду на це Стратегія має охоплювати ключові напрями зі створення та випуску товарів, зокрема:

біологічні препарати та проміжні продукти для їхнього виробництва (ЛЗ на основі антитіл; ЛП на основі рекомбінантних білків; вакцини; препарати нуклеїнових кислот і продукти для клітинної терапії; технології розробки біологічних препаратів);

хімічні препарати та проміжні продукти для їхнього виробництва (нові синтезовані хімічні Л3, хімічні генерики, високоефективні препарати, технології розробки хімічних препаратів);

медичне обладнання (медичне обладнання для візуалізації, медичні вироби для in vitro діагностики, лікувальне устаткування, МВ для проведення інтервенційних втручань, медичні матеріали);

фармацевтичні наповнювачі та система упаковки (фармацевтичні допоміжні речовини та функціональні матеріали, система пакування й доставки ліків);

обладнання та апаратура для фармацевтики (розробка сучасного устаткування, технології виробництва).

Реалізація Стратегії має здійснюватися на базі цілеспрямованого, проблемно-орієнтованого підходу й фокусуватися на таких аспектах:

- прискорення модернізації й збільшення масштабів ВТФТ діючими компаніями, формування національних технологічних чемпіонів;

- запуск стартапів, що спираються на розробки, впровадження яких сприятимуть технологічним інноваціям у фармацевтиці;

- створення нових фармацевтичних компаній (зокрема 3 контрактного виробництва ТНК для залучення передових іноземних технологій 3 метою посилення ендогенного інноваційного потенціалу галузі).

Тож ключовими стратегічними пріоритетами мають стати:

технологічні інновації (нарощування інноваційного потенціалу галузі; прискорення запровадження у фармацевтичне виробництво інформаційно-комунікаційних технологій нового покоління; сприяння формуванню нових бізнес-моделей фармацевтичних виробників);

співробітництво та кооперація (поліпшення науково-технологічної та інноваційної співпраці фармацевтичних компаній з академічним та освітнім секторами; формування (подовження) ланцюгів доданої вартості

${ }^{6}$ Це обумовлено необхідністю врахування негативного досвіду країн Латинської Америки, які в процесі розвитку фармацевтики в контексті стратегії імпортозаміщення здебільшого спиралися на іноземні технології та засоби виробництва, що призвело до структурних проблем, погіршення торговельного балансу та девальвації національної валюти. Хоча урядами цих країн зроблено спробу «замкнути» міжсекторальні ланцюги через освоєння випуску засобів виробництва, значна технологічна залежність від розвинених країн (яку закладено від початку у фундамент розбудови галузі) суттєво обмежила державний вплив на створення ендогенних ресурсів, що загальмувало розвиток. 
в Україні через налагодження (зміцнення) технологічних і виробничих зав'язків між суб'єктами господарювання;

міжнародна співпраця (розширення наукового та промислового співробітництва з СС задля розвитку технологій, кадрів, виробничих потужностей та забезпечення капіталом; створення привабливих умов іноземним компаніям для налагодження в Україні науково-дослідних і промислових майданчиків 3 метою здійснення контрактних клінічних випробувань та виробництва нових ліків);

якість та ефективність (посилення відповідальності виробників щодо якості готової фармацевтичної продукції; вдосконалення системи стандартів якості та контролю за якістю й безпекою; сприяння підвищенню якості й ефективності проміжних хімічних і біологічних продуктів);

імпортозаміщення, стабільність поставок на внутрішній ринок (освоєння виробництва важливих субстанцій (проміжних товарів) для фармацевтичного виробництва; забезпечення необхідного запасу ліків, поліпшення системи зберігання ліків і мережі їхнього розподілу; створення умов для безпеки постачання);

вихід на зовнішні ринки (підвищення міжнародної конкурентоспроможності фармацевтичних товарів, запровадження стимулів для збільшення експорту та посилення позицій України на європейському ринку);

екологія, «зелена» фармащевтика (попередження негативного впливу та зниження негативних наслідків від фармацевтичних відходів на організм людини та довкілля; контроль за належним поводженням з фармацевтичними відходами та оцінка їхнього екологічного ризику; сприяння формуванню виробничо-технологічних систем, заснованих на циркулярних принципах; зменшення споживання енергії, викидів $\mathrm{CO}_{2}$, споживання води, викидів летких органічних речовин, покращення екологічності хімічних сполук для потреб фармацевтики);

розумне виробництво (збільшення рівня автоматизації та інформатизації процесу виробництва фармацевтичної продукції, використання штучного інтелекту та машинного навчання, технологій додаткової та віртуальної реальності, цифрових програм, інтернету речей, $3 D$-друку.

Для реалізації визначених пріоритетів необхідним є виконання низки завдань, реалізація яких вимагає запровадження нормативноправових та організаційно-інституційних заходів, а також організаційних i заходів з популяризації вітчизняної фармацевтичної промисловості (ці пропозиції детально викладено у праці [36]). Для прискорення розвитку ВТФВ варто розробити низку документів.

По-перше, Державну науково-технічну комплексну програму розвитку фармацевтичної та суміжних галузей промисловості України, що охоплюватиме розробку нових біологічних і хімічних субстанцій і лікарських засобів; медичних виробів (медичної техніки та виробів медичного призначення); нових наповнювачів і пакувальних матеріалів, а також машин та устаткування для фармацевтичного виробництва; 
По-друге, Державну програму технологічних інновацій та цифровізації фармацевтичного виробництва та суміжних галузей промисловості України, що реалізуватиметься на засадах державноприватного партнерства й сприятиме освоєнню у виробництві та виведенню на ринок інноваційних товарів на базі вітчизняних розробок з високим рівнем локалізації виробництва;

По-третє, Державну програму «Нові українські ліки, медичні вироби та продукти суміжних виробництв», у рамках якої започаткувати ідентифікацію та сертифікацію товарів фармацевтичної та суміжних галузей промисловості, що відповідатимуть критеріям «високотехнологічний продукт, створений на базі ендогенних інновацій», та надання преференцій за їх закупівель. Це дасть змогу зростити національних «технологічних чемпіонів» 3 опорою на національні інноваційні надбання [39].

3 огляду на нові настанови політики СС щодо фармацевтики, зокрема, тенденції решорингу виробництв з Азії, наявні в Україні виробничі потужності можуть стати платформою для форсованого налагодження випуску інгредієнтів і готових ЛЗ та МВ на діючих інноваційних підприємствах. Зважаючи на потенціал та перспективи української хімічної та фармацевтичної індустрії, у рамках реалізації Стратегії керівництву країни доцільно запровадити податкові стимули та компенсаційні механізми для заохочення таких інноваційноінвестиційних проєктів. Це сприятиме перетворенню України не лише на привабливий майданчик для решорингу АФI, але й створить передумови для започаткування нових виробництв проміжних продуктів Л3 та МВ для забезпечення потреб фармацевтичних виробників України та країн СС.

Висновки. Керівництво СС дотримується багаторічної позиції щодо пріоритетності розвитку фармацевтики у контексті реалізації як промислової політики, так і політики у сфері охорони здоров'я, але спалах COVID-19 виявив уразливість європейської фармацевтики, продемонструвавши реальні загрози в частині порушення ланцюжків поставок АФІ та інших проміжних товарів для безперебійної роботи галузі. Кризові явища спонукали керівництво СС ухвалити нові стратегічні документи, що обгрунтували доцільність розширення лінійки продуктів діючих компаній у країнах - членах $\mathrm{CC}$, налагодження «3 нуля» та перенесення окремих виробництв АФІ та готових ЛЗ і МВ 3 азійських країн. Нові стратегічні документи $\mathrm{CC}$, що визначили пріоритетом зменшення стратегічної зовнішньої залежності від імпорту, а також запровадження заходів, що сприятимуть збільшенню ефективності наявних ліків і підвищення їхньої якості мають стати орієнтирами для розробки політики розвитку ВТФВ України в умовах євроінтеграції.

В Україні за останні 20 років створено нормативно-правовий фундамент щодо ліцензування, реєстрації, стандартизації, сертифікації 
та контролю у сфері Л3, що загалом спирається на керівні принципи, визначені $\mathrm{CC}$ і BOO3. Імплементовано настанови належних міжнародних стандартів. Ці заходи створюють підгрунтя для збільшення якості, ефективності й безпеки ЛЗ, а також процесів їхнього виробництва та пакування; поліпшують техніко-економічні параметри на етапах ДіР; сприяють впровадженню передових технологій, модернізації виробництва, підвищенню продуктивності праці; розвитку міжнародного співробітництва та усуненню технічних бар'єрів у торгівлі. Водночас євроінтеграційні процеси, що відбувалися протягом багатьох років, спрямовано передусім на гармонізацію законодавчого та нормативно-правового регулювання діяльності з виробництва ЛЗ і МВ, а не на нарощування потенціалу ендогенного розвитку галузі. Разом 3 тим, Україна, унормувавши відповідно до вимог СС діяльність галузі, не має (на відміну від країн ЄС) доступу до фондів СС, завдяки яким покривається частина витрат фармацевтичних компаній країн-членів на розвиток ДіР інфраструктури й реалізацію науково-технологічних та інноваційних проєктів. Це ставить вітчизняні компанії у неконкурентні умови 3 європейськими виробниками, для яких український ринок став перспективним щодо збуту ЛЗ та МВ.

Попри значну кількість актуальних фахових науково-прикладних доробок щодо вдосконалення політики розвитку фармацевтики, брак політичної волі й послідовності в ухваленні рішень і міжвідомча неузгодженість в ухваленні розроблених проєктів НПА, невідповідність планів заходів завданням прийнятих програм, відсутність виконавської дисципліни за реалізації затверджених заходів загальмували розвиток ВТФВ України. Чинні в Україні НПА регулюють правовідносини у фармацевтичному секторі в контексті євроінтеграційних процесів, проте не визначають а ні пріоритети галузі та заходи їх досягнення, а ні механізми їхньої реалізації. Ухвалена Національна економічна стратегія на період до 2030 р. передбачає лише формування національної фармацевтичної (лікарської) політики, тоді як СС, як показало дослідження, приділяє також увагу промисловій політиці для фармацевтичної індустрії.

Задля прискорення розбудови ВТФВ в умовах євроінтеграції необхідним кроком $\epsilon$ створення Стратегії розвитку ВТФВ України в рамках промислової політики, в основі якої має бути комплексний підхід до вирішення проблем галузі, зокрема орієнтація не лише на ЛЗ i MB, а й на фармацевтичні інгредієнти (хімічні та біологічні), наповнювачі та упаковку, обладнання та апаратуру для фармацевтики. Це, з одного боку, сприятиме зменшенню залежності фармацевтики від імпорту та попередить проблему «усіченої індустріалізації», що веде до погіршення платіжного балансу; з іншого - активізує діяльність суміжних виробництв, збільшить зайнятість та надходження до бюджетів усіх рівнів.

3 огляду на відповідальність урядів дбати про здоров'я нації, забезпечувати ефективність економічної системи та соціальну 
стабільність, сприяти появі нових ефективних ЛЗ і МВ на базі передових технологій, зменшувати залежність від імпорту заходи зі сприяння розбудові хіміко-фармацевтичних підприємств, зокрема з виробництва АФІ на території України в контексті нових настанов політики ЄС щодо решорингу, можуть стати раціональним, політично виправданим рішенням.

\section{СПИСОК ВИКОРИСТАНИХ ДЖЕРЕ}

1. Доровський О. В. Обгрунтування вибору стратегії розвитку фармацевтичної галузі України: автореф. дис ... д-ра екон. наук: 08.00.03. Харків, 2015. 32 с.

2. Костюк Г., Маргітич В. Про національну стратегію забезпечення ліками в Україні. Дзеркало тижня. 2017. URL: https://zn.ua/ukr/promyshli-ennost/ pro-nacionalnu-strategiyu-zabezpechennyalikami-v-ukrayini.html.

3. Сіденко В. Переформатування європейської інтеграції: можливості і ризики для асоціації Україна-СС. Київ: Заповіт, 2018. 214 с.

4. Секторальна інтеграція України до СС: передумови, перспективи, виклики. Київ: Заповіт, 2020.99 с.

5. Пашков В. М. Правове забезпечення імплементації законодавства СС щодо обігу лікарських засобів. Медичне право. 2016. № 2. С. 55-62.

6. Нікітюк В., Шаікіна Т. Фармацевтична галузь України - інтеграція в європейський та світовий ринок чи тупцювання на місці? Щотижневик аптека. 2019. № 1. URL: https://www.apteka.ua/article/510294.

7. Вдовиченко В., Зосименко Т. Панденоміка Свропи: політичні, економічні та соціальні виклики вакцинування від COVID-19. Аналітична записка програм Європейських студій та Економічної дипломатії Ради зовнішньої політики «Українська призма» в рамках проєкту Інституційного розвитку аналітичних центрів за підтримки Посольства Швеції в Україні. Ініціативи відкритого суспільства для Свропи (OSIFE) та Міжнародного фонду «Відродження». 2021. URL: https:/elibrary.kubg.edu.ua/id/eprint/36672/1/V_Vdovychenko_PE_ 2021_FPMV.pdf.

8. Кораблін С. О. Державне регулювання як чинник протидії COVID-19. Економіка України. 2021. № 7. С. 27-40. URL: https://doi.org/10.15407/ economyukr.2021.07.027.

9. Commission communication to the Council and Parliament on the outlines of an industrial policy for the pharmaceutical sector in the European Community. COM (93) 718, 02.03.94. URL: https://op.europa.eu/mt/ publication-detail/-/ publication/6af1ca21-939d-11e9-9369-01aa75ed71a1/language-en/format-PDF/ source-search.

10. Industrial policy and the pharmaceutical industry. The Proceedings of a Symposium held on 22nd June 1994, London/ Edited by Adrian Towse. Office of Health Economics. URL: https://www.ohe.org/system/files/ private/ publications/217\%20-\%201995_Industrial_Policy_Towse_FULL.pdf.

11. Industrial policy for the pharmaceutical sector. Debates $1 \overline{6}$ April 1996. URL: https://www.europarl.europa.eu/doceo/document/CRE-4-1996-04-16-ITM-003 EN.html.

12. Council Resolution designed to implement the outlines of an industrial policy in the pharmaceutical sector in the European Union. 1996. URL: https://op.europa.eu/ga/publication-detail/-/publication/bf15f43c-6a8b-49538155-04fc004albe3/language-en. 
13. Pharmaceutical Industry: A Strategic Sector for the European Economy. European Commission. Commission Staff Working Document. 2014. URL: https://ec.europa.eu/growth/content/pharmaceutical-industry-strategic-sectoreuropean-economy-0_en.

14. Innovative Medicines Initiative. URL: https://www.imi.europa.eu.

15. Саліхова О. Б., Гончаренко Д. О. Ендогенізація економічного розвитку через розбудову високотехнологічних фармацевтичних виробництв: досвід Європи, уроки для України. Бізнес Інформ. 2020. № 2. С. 49-56. URL: https://doi.org/10.32983/2222-4459-2020-2-49-56.

16. The State of U. S. Science and Engineering 2020. URL: https://ncses.nsf.gov/ pubs/nsb20201.

17. European Commission. Communication from the Commission. Guidelines on the Optimal and Rational Supply of Medicines to Avoid Shortages during the COVID-19 Outbreak. 8.4.2020, COM. 2272 Final. Brussels. URL: https://ec.europa.eu/info/sites/default/files/communication-commission-guidelinesoptimal-rational-supply-medicines-avoid.pdf.

18. Affordable, accessible and safe medicines for all: the Commission presents a Pharmaceutical Strategy for Europe. URL: https://ec.europa.eu/commission/ presscorner/detail/en/ip_20_2173.

19. Updating the 2020 Industrial Strategy: towards a stronger Single Market for Europe's recovery. URL: https://ec.europa.eu/commission/presscorner/detail/ en/IP_21_1884.

20. Madner V., Mayr S., Sauca I., 2021. Analyse der rechtlichen Rahmenbedingungen für Maßnahmen zur Steigerung von Versorgungssicherheit und Resilienz. Working Paper Reihe der AK Wien - Materialien zu Wirtschaft und Gesellschaft 217, Kammer für Arbeiter und Angestellte für Wien, Abteilung Wirtschaftswissenschaft und Statistik. URL: https://ideas.repec.org/p/clr/ mwugar/217.html.

21. Хоменко В. М. Теоретичне обгрунтування та реалізація сучасних принципів державного управління фармацією в Україні: автореф. дис. на здобуття наукового ступеня д. фарм. Н.: 15.00.01. Харків, 2008. 42 с.

22. Проєкт концепції Державної цільової програми «Розвиток імпортозамінних виробництв в Україні та заміщення імпортованих лікарських засобів вітчизняними, у тому числі біотехнологічними препаратами та вакцинами на 2011-2021 роки». URL: https://www.apteka.ua/article/78579.

23. Концепція розвитку фармацевтичної галузі України. URL: https://www.apteka.ua/article/2231.

24. Проєкт Концепції Державної цільової програми створення вітчизняних імунобіологічних препаратів «Українська вакцина» на 2011-2015 р. URL: https://www.apteka.ua/article/28692.

25. Концепція розвитку імпортозамінних виробництв - загроза фармацевтичній галузі та безпеці населення України. Інтерфакс-Україна. 2011. URL: https://ua.interfax.com.ua/news/press-release/68941.html.

26. МО3 розробляє Концепцію державної програми розвитку імпортозамінних виробництв в Україні. URL: https://www.kmu.gov.ua/news/ 249097923.

27. Про схвалення Концепції Державної цільової науково-технічної програми створення та проведення доклінічних випробувань вітчизняних лікарських засобів для забезпечення охорони здоров'я людини та задоволення потреб ветеринарної медицини на 2011-2015 р. Розпорядження КМУ від 
6 грудня 2010 p. № 2245. URL: https://zakon.rada.gov.ua/laws/show/2245$2010-\% \mathrm{D} 1 \% 80 \#$ Text.

28. Державна цільова науково-технічна програма розроблення новітніх технологій створення вітчизняних лікарських засобів для забезпечення охорони здоров'я людини та задоволення потреб ветеринарної медицини на 2011-2015 роки. Постанова КМУ № 725 від 22.06.2011 p. URL: https://zakon.rada.gov.ua/ laws/show/725-2011-\%D0\%BF\#Text.

29. Підбито підсумки реалізації Державної науково-технічної програми розроблення новітніх технологій створення вітчизняних ліків у 2012 p. URL: https://www.apteka.ua/article/201885.

30. Про затвердження Концепції розвитку фармацевтичного сектору галузі охорони здоров'я України на 2011-2020 роки: Наказ МО3 № 769 від 13.09.2010. URL: https://zakononline.com.ua/documents/show/25438_ 539786.

31. Про затвердження Плану заходів щодо виконання Концепції розвитку фармацевтичного сектору галузі охорони здоров'я України на 20112020 pp. URL: https://zakononline.com.ua/documents/show/56725_ 56725.

32. Про затвердження Державної програми стимулювання економіки для подолання негативних наслідків, спричинених обмежувальними заходами щодо запобігання виникненню і поширенню гострої респіраторної хвороби COVID-19, спричиненої коронавірусом SARS-CoV-2, на 20202022 pp. Постанова КМУ № 534 від 27 травня 2020 p. URL: zakon.rada.gov.ua/ laws/show/534-2020-\%D0\%BF\#Text.

33. Проєкт розпорядження Кабінету Міністрів України «Про схвалення Концепції Державної цільової програми створення та розвитку внутрішнього виробництва високоякісних лікарських засобів для профілактики і лікування особливо небезпечних інфекційних та інших хвороб» для забезпечення державних потреб України на 2021-2026 pp. URL: https://moz.gov.ua.

34. Повідомлення НАН України. Засідання Президії НАН України 9 червня 2021 року. URL: https://www.nas.gov.ua/UA/Messages/Pages/View.aspx? MessageID=7891.

35. Про затвердження Національної економічної стратегії на період до 2030 року. Постанова КМУ № 179 від 03 березня 2021 p. URL: https://www.kmu.gov.ua/ npas/pro-zatverdzhennya-nacionalnoyi-eko-a179.

36. Саліхова О. Б., Гончаренко Д. О. Політика розбудови фармацевтичної індустрії в Німеччині: Уроки для України. Економіка України. 2020. № 10. C. 63-86. URL: https://doi.org/10.15407/economyukr.2020.10.063.

37. Саліхова О. Б., Гончаренко Д. О. Політика ендогенного розвитку фармацевтики в Китаї: уроки для України. Економіка та прогнозування. 2020. № 2. C. 139-157. URL: https://doi.org/10.15407/eip2020.02.139.

38. Саліхова О. Б., Гончаренко Д. О. Концептуальні засади стратегії розвитку високотехнологічної індустрії лікарських засобів та медичних виробів в Україні до 2030 р. Бізнес Інформ. 2020. № 7. C. 28-35. DOI: 10.32983/22224459-2020-7-28-35.

39. Саліхова Е. Б., Гончаренко Д. О. Фармацевтика України: від залежності до ендогенного розвитку. Економіка та прогнозування. 2020. № 4. С.7-35. DOI: $10.15407 /$ eip2020.04.007.

Стаття надійшла до редакиії 06.07.2021. 
Salikhova O. B., Honcharenko D. O. High-tech pharmaceutical manufacturing in Ukraine: challenges of European integration.

Background. The crisis COVID-19 pandemic has highlighted that EU have strategic dependencies, particularly in the most sensitive industrial ecosystems such as for health. Ukraine implements the policy of European economic integration and the development of the pharmaceutical sector must take into account both European considerations and national interests.

Analysis of recent researches and publications revealed that the crisis COVID-19 pandemic revealed pharmaceutical industry problems; that require further study for adequate reproduction of the best practices in Ukraine.

The aim of the article is to explore the EU experience, to define and justify the necessary policy measures for the development of pharmaceuticals in Ukraine in the context of European integration.

Materials and methods. The theoretical and methodological basis for writing the article was the works of domestic and foreign scholars on the outlines of an industrial policy for the pharmaceutical sector. The research was conducted using the methods of theoretical generalization, comparative analysis, analysis and synthesis, which made it possible to justify the need for changes in the management of high-tech pharmaceutical industries development in Ukraine.

Results. The regulations in force in Ukraine regulate legal relations in the pharmaceutical sector in the context of EU integration, but do not define the priorities of the sector and the measures to achieve them or the mechanisms for their implementation. Recommendations for Ukraine have been given, the implementation of which will accelerate the development of national high-tech pharmaceutical industries and related sectors of the economy taking into account changes in EU policy.

Conclusion. In Ukraine, first of all it is necessary to define the conceptual foundations of the strategy of development of the high-tech industry of pharmaceuticals and medical products, based on the modern challenges and threats, as well as global trends in the technology development; to build an effective decision making vertical on the implementation of industrial policy for the pharmaceutical sector, identify strategic priorities and evaluate the necessary funding, to introduce state support programs, introduce instruments to stimulate domestic demand for Ukrainian pharmaceutical and medical products, make changes to the public procurement system for the development of industry for national security purposes. Recommendations are proposed as to: improving the normative-legal and institutional principles of the development of pharmaceutical industry; strengthening the cooperation of the State, academic, educational, private sector and public; creating stable resources of funding programs and projects on the basis of public-private partnerships.

Keywords: EU, Ukraine, European integration, pharmaceutical sector, industrial policy, strategy, pharmaceuticals, medical products, high-technologies, innovation.

\section{REFERENCES}

1. Dorovs'kyj, O. V. (2015). Obg'runtuvannja vyboru strategii' rozvytku farmacevtychnoi' galuzi Ukrai'ny [Justification of the choice of strategy for the development of the pharmaceutical industry of Ukraine] Extended abstract of Doctor's thesis. Harkiv [in Ukrainian]. 
2. Kostjuk, G., \& Margitych, V. (2017). Pro nacional'nu strategiju zabezpechennja likamy v Ukrai'ni [On the national drug supply strategy in Ukraine]. Dzerkalo tyzhnja - Mirror of the week. Retrieved from https://zn.ua/ukr/promyshliennost/pronacionalnu-strategiyu-zabezpechennya-likami-v-ukrayini-_html [in Ukrainian].

3. Sidenko, V. (2018). Pereformatuvannja jevropejs'koi' integracii': mozhlyvosti $i$ ryzyky dlja asociacii' Ukrai'na-JeS [Reformatting European integration: opportunities and risks for the Ukraine-EU association]. Kyi'v: Zapovit [in Ukrainian].

4. Sektoral'na integracija Ukrai'ny do JeS: peredumovy, perspektyvy, vyklyky [Ukraine's sectoral integration into the EU: preconditions, prospects, challenges]. (2020). Kyi'v: Zapovit [in Ukrainian].

5. Pashkov, V. M. (2016). Pravove zabezpechennja implementacii' zakonodavstva JeS shhodo obigu likars'kyh zasobiv [Legal support for the implementation of EU legislation on the circulation of medicines]. Medychne pravo-Medical law, 2, 55-62 [in Ukrainian].

6. Nikitjuk, V., \& Shaikina, T. (2019). Farmacevtychna galuz' Ukrai'ny - integracija v jevropejs'kyj ta svitovyj rynok chy tupcjuvannja na misci? [Ukraine's pharmaceutical industry - integration into the European and world markets or stamping on the same place?] Shhotyzhnevyk apteka - Weekly pharmacy, 1. Retrieved from https://www.apteka.ua/article/510294. [in Ukrainian].

7. Vdovychenko, V., \& Zosymenko, T. (2021). Pandenomika Jevropy: politychni, ekonomichni ta social'ni vyklyky vakcynuvannja vid COVID-19. Analitychna zapyska program Jevropejs'kyh studij ta Ekonomichnoi' dyplomatii' Rady zovnishn'oi' polityky «Ukrai'ns'ka pryzma» v ramkah proektu Instytucijnogo rozvytku analitychnyh centriv za pidtrymky Posol'stva Shvecii' v Ukrai'ni. Iniciatyvy vidkrytogo suspil'stva dlja Jevropy (OSIFE) ta Mizhnarodnogo fondu «Vidrodzhennja» [Pandenomics of Europe: political, economic and social challenges of COVID-19 vaccination. Analytical note of the programs of European Studies and Economic Diplomacy of the Foreign Policy Council «Ukrainian Prism» in the framework of the project of Institutional Development of analytical centers with the support of the Embassy of Sweden in Ukraine. Open Society Initiatives for Europe (OSIFE) and the International Foundation «Renaissance».]. Retrieved from https:/elibrary.kubg.edu.ua/ id/eprint/36672/1/V_Vdovychenko_PE_2021_FPMV.pdf. [in Ukrainian].

8. Korablin, S. O. (2021). Derzhavne reguljuvannja jak chynnyk protydii' COVID-19 [State regulation as a factor in counteracting COVID-19]. Ekonomika Ukrai'ny Ukraine economy, 7, 27-40. Retrieved from https://doi.org/10.15407/ economyukr.2021.07.027 [in Ukrainian].

9. Commission communication to the Council and Parliament on the outlines of an industrial policy for the pharmaceutical sector in the European Community. COM (93) 718, 02.03.94. Retrieved from https://op.europa.eu/mt/publication-detail/ -/publication/6af1 ca21-939d-11e9-9369-01 aa75ed71a1/language-en/format-PDF/ source-search [in English].

10. Industrial policy and the pharmaceutical industry. The Proceedings of a Symposium held on 22nd June 1994, London/ Edited by Adrian Towse. Office of Health Economics. Retrieved from https://www.ohe.org/system/files/private/publications/ 217\%20-\%201995_Industrial_Policy_Towse_FULL.pdf [in English].

11. Industrial policy for the pharmaceutical sector. Debates 16 April 1996. Retrieved from https://www.europarl.europa.eu/doceo/document/CRE-4-1996-04-16-ITM-003 EN.html [in English].

12. Council Resolution designed to implement the outlines of an industrial policy in the pharmaceutical sector in the European Union. 1996. Retrieved from https://op.europa.eu/ga/publication-detail/-/publication/bf15f43c-6a8b-4953-815504fc004albe3/language-en [in English]. 
13. Pharmaceutical Industry: A Strategic Sector for the European Economy. European Commission. Commission Staff Working Document. 2014. Retrieved from https://ec.europa.eu/growth/content/pharmaceutical-industry-strategic-sector-europeaneconomy-0_en [in English].

14. Innovative Medicines Initiative. URL: https://www.imi.europa.eu [in English].

15. Salihova, O. B., \& Goncharenko, D. O. (2020). Endogenizacija ekonomichnogo rozvytku cherez rozbudovu vysokotehnologichnyh farmacevtychnyh vyrobnyctv: dosvid Jevropy, uroky dlja Ukrai'ny [Endogenization of economic development through the development of high-tech pharmaceutical industries: the experience of Europe, lessons for Ukraine]. Biznes Inform - Business Inform, 2, 49-56. Retrieved from https://doi.org/10.32983/2222-4459-2020-2-49-56 [in Ukrainian].

16. The State of U. S. Science and Engineering 2020. Retrieved from https://ncses.nsf.gov/pubs/nsb20201 [in English].

17. European Commission. Communication from the Commission. Guidelines on the Optimal and Rational Supply of Medicines to Avoid Shortages during the COVID-19 Outbreak. 8.4.2020, COM. 2272 Final. Brussels. Retrieved from https://ec.europa.eu/info/sites/default/files/communication-commission-guidelinesoptimal-rational-supply-medicines-avoid.pdf [in English].

18. Affordable, accessible and safe medicines for all: the Commission presents a Pharmaceutical Strategy for Europe. Retrieved from https://ec.europa.eu/commission/ presscorner/detail/en/ip_20_2173 [in English].

19. Updating the 2020 Industrial Strategy: towards a stronger Single Market for Europe's recovery. Retrieved from https://ec.europa.eu/commission/presscorner/detail/en/ IP_21_1884 [in English].

20. Madner, V., Mayr, S., \& Sauca, I. (2021). Analyse der rechtlichen Rahmenbedingungen für Maßnahmen zur Steigerung von Versorgungssicherheit und Resilienz. Working Paper Reihe der AK Wien - Materialien zu Wirtschaft und Gesellschaft 217, Kammer für Arbeiter und Angestellte für Wien, Abteilung Wirtschaftswissenschaft und Statistik. Retrieved from https://ideas.repec.org/p/clr/mwugar/217.html [in English].

21. Homenko, V. M. (2008). Teoretychne obg'runtuvannja ta realizacija suchasnyh pryncypiv derzhavnogo upravlinnja farmacijeju v Ukrai'ni: abstract of dis. for the obtaining a scientific degree of Dr. of Pharm. S.: 15.00.01. Harkiv [in Ukrainian].

22. Projekt koncepcii' Derzhavnoi' cil'ovoi' programy «Rozvytok importozaminnyh vyrobnyctv v Ukrai'ni ta zamishhennja importovanyh likars'kyh zasobiv vitchyznjanymy, u tomu chysli biotehnologichnymy preparatamy ta vakcynamy na 2011-2021 roky» [Draft concept of the State target program «Development of import-substituting industries in Ukraine and replacement of imported drugs with domestic ones, including biotechnological drugs and vaccines for 2011-2021»]. Retrieved from https://www.apteka.ua/article/78579 [in Ukrainian].

23. Koncepcija rozvytku farmacevtychnoi' galuzi Ukrai'ny [The concept of development of the pharmaceutical industry of Ukraine]. Retrieved from https://www.apteka.ua/ article/2231 [in Ukrainian].

24. Projekt Koncepcii' Derzhavnoi' cil'ovoi' programy stvorennja vitchyznjanyh imunobiologichnyh preparativ «Ukrai'ns'ka vakcyna» na 2011-2015 r. [Draft Concept of the State Target Program for the Development of Domestic Immunobiological Drugs «Ukrainian Vaccine» for 2011-2015]. Retrieved from https://www.apteka.ua/article/28692 [in Ukrainian].

25. Koncepcija rozvytku importozaminnyh vyrobnyctv - zagroza farmacevtychnij galuzi ta bezpeci naselennja Ukrai'ny [The concept of development of import-substituting industries is a threat to the pharmaceutical industry and the safety of the population of Ukraine. (2011). Interfaks - Interfax-Ukraine. Retrieved from https:/ua.interfax.com.ua/ news/press-release/68941.html [in Ukrainian]. 
26. MOZ rozrobljaje Koncepciju derzhavnoi' programy rozvytku importozaminnyh vyrobnyctv v Ukrai'ni [The Ministry of Health is developing the Concept of the state program for the development of import-substituting industries in Ukraine]. Retrieved from https://www.kmu.gov.ua/news/249097923 [in Ukrainian].

27. Pro shvalennja Koncepcii' Derzhavnoi' cil'ovoi' naukovo-tehnichnoi' programy stvorennja ta provedennja doklinichnyh vyprobuvan' vitchyznjanyh likars'kyh zasobiv dlja zabezpechennja ohorony zdorov'ja ljudyny ta zadovolennja potreb veterynarnoi' medycyny na 2011-2015 r. Rozporjadzhennja KMU vid 6 grudnja 2010 r. № 2245. [About approval of the Concept of the State target scientific and technical program of creation and carrying out preclinical trials of domestic medicines for ensuring human health care and satisfaction of needs of veterinary medicine for 2011-2015. Order of the Cabinet of Ministers of December 6, 2010 № 2245]. Retrieved from https://zakon.rada.gov.ua/laws/show/2245-2010-\%D1\%80 \#Text [in Ukrainian].

28. Derzhavna cil'ova naukovo-tehnichna programa shhodo rozroblennja novitnih tehnologij stvorennja vitchyznjanyh likars'kyh zasobiv dlja zabezpechennja ohorony zdorov'ja ljudyny ta zadovolennja potreb veterynarnoi' medycyny na 20112015 roky. Postanova KMU № 725 vid 22.06.2011 r. [The state target scientific and technical program for the development of the latest technologies for the creation of domestic medicines to ensure human health care and meet the needs of veterinary medicine for 2011-2015. Resolution of the Cabinet of Ministers of Ukraine № 725 of June 22, 2011] URL: https://zakon.rada.gov.ua/laws/show/725-2011-\%D0\%BF\#Text [in Ukrainian].

29. Pidbyto pidsumky realizacii' Derzhavnoi' naukovo-tehnichnoi' programy rozroblennja novitnih tehnologij stvorennja vitchyznjanyh likiv u 2012 r. [The results of the implementation of the State scientific and technical program for the development of new technologies for the creation of domestic drugs in 2012 are summarized.] Retrieved from https://www.apteka.ua/article/201885 [in Ukrainian].

30. Pro zatverdzhennja Koncepcii' rozvytku farmacevtychnogo sektoru galuzi ohorony zdorov'ja Ukrai'ny na 2011-2020 roky: Nakaz MOZ № 769 vid 13.09.2010. [On approval of the Concept of development of the pharmaceutical sector of the healthcare branch of Ukraine for 2011-2020: Order of the Ministry of Health № 769 dated 13.09.2010]. Retrieved from https://zakononline.com.ua/documents/show/ $25438 \quad 539786$ [in Ukrainian].

31. Pro zatverdzhennja Planu zahodiv shhodo vykonannja Koncepcii' rozvytku farmacevtychnogo sektoru galuzi ohorony zdorov'ja Ukrai'ny na 2011-2020 rr. [On approval of the Action Plan for the implementation of the Concept of the pharmaceutical sector development of the healthcare branch of Ukraine for 20112020]. Retrieved from https://zakononline.com.ua/documents/show/56725 56725 [in Ukrainian].

32. Pro zatverdzhennja Derzhavnoi' programy stymuljuvannja ekonomiky dlja podolannja negatyvnyh naslidkiv, sprychynenyh obmezhuval'nymy zahodamy shhodo zapobigannja vynyknennju i poshyrennju gostroi' respiratornoi' hvoroby COVID-19, sprychynenoi' koronavirusom SARS-CoV-2, na 2020-2022 rr. Postanova KMU № 534 vid 27 travnja 2020 r. [On approval of the State Program of Economic Stimulation to overcome the negative consequences caused by restrictive measures to prevent the occurrence and spread of acute respiratory disease COVID-19 caused by coronavirus SARS-CoV-2, for 2020-2022. Resolution of the Cabinet of Ministers of Ukraine № 534 of May 27, 2020.] Retrieved from zakon.rada.gov.ua/ laws/show/534-2020-\%D0\%BF\#Text [in Ukrainian].

33. Projekt rozporjadzhennja Kabinetu Ministriv Ukrai'ny «Pro shvalennja Koncepcii' Derzhavnoi' cil'ovoi' programy stvorennja ta rozvytku vnutrishn'ogo vyrobnyctva vysokojakisnyh likars'kyh zasobiv dlja profilaktyky i likuvannja osoblyvo 
nebezpechnyh infekcijnyh ta inshyh hvorob dlja zabezpechennja derzhavnyh potreb Ukrai'ny na 2021-2026 rr.» [ Draft order of the Cabinet of Ministers of Ukraine «On approval of the Concept of the State target program for the creation and development of domestic production of high quality drugs for the prevention and treatment of particularly dangerous infectious and other diseases to meet the state needs of Ukraine for 2021-2026».]. Retrieved from https://moz.gov.ua [in Ukrainian].

34. Povidomlennja NAN Ukrai'ny. Zasidannja Prezydii' NAN Ukrai'ny 9 chervnja 2021 roku. [Draft order of the Cabinet of Ministers of Ukraine «On approval of the Concept of the State target program for the creation and development of domestic production of high quality drugs for the prevention and treatment of particularly dangerous infectious and other diseases to meet the state needs of Ukraine for 2021-2026».]. Retrieved from https://www.nas.gov.ua/UA/Messages/Pages/ View.aspx?MessageID=7891 [in Ukrainian].

35. Pro zatverdzhennja Nacional'noi' ekonomichnoi' strategii' na period do 2030 roku. Postanova KMU № 179 vid 03 bereznja 2021 r. [On approval of the National Economic Strategy for the period up to 2030. Resolution of the Cabinet of Ministers of Ukraine № 179 of March 3, 2021]. Retrieved from https://www.kmu.gov.ua/npas/pro-zatverdzhennya-nacionalnoyi-eko-a179 [in Ukrainian].

36. Salihova, O. B., \& Goncharenko, D. O. (2020). Polityka rozbudovy farmacevtychnoi' industrii' v Nimechchyni: Uroky dlja Ukrai'ny [Polityka rozbudovy farmacevtychnoi' industrii' v Nimechchyni: Uroky dlja Ukrai'ny]. Ekonomika Ukrai'ny - Ukraine economy, 10, 63-86. DOI: 10.15407/economyukr.2020.10.063 [in Ukrainian].

37. Salihova, O. B., \& Goncharenko, D. O. (2020). Polityka endogennogo rozvytku farmacevtyky v Kytai': uroky dlja Ukrai'ny [The policy of endogenous development of pharmaceuticals in China: lessons for Ukraine]. Ekonomika ta prognozuvannja Economics and forecasting, 2, 139-157. DOI: 10.15407/eip2020.02.139 [in Ukrainian].

38. Salihova, O. B., \& Goncharenko, D. O. (2020). Konceptual'ni zasady strategii' rozvytku vysokotehnologichnoi' industrii' likars'kyh zasobiv ta medychnyh vyrobiv v Ukrai'ni do 2030 r. [Conceptual bases of strategy of development of the high-tech industry of medicines and medical devices in Ukraine till 2030]. Biznes Inform Business Inform, 7, 28-35. Retrieved from https://doi.org/10.32983/2222-4459-20207-28-35 [in Ukrainian].

39. Salihova, O. B., \& Goncharenko, D. O. (2020). Farmacevtyka Ukrai'ny: vid zalezhnosti do endogennogo rozvytku [Pharmaceuticals of Ukraine: from dependence to endogenous development]. Ekonomika ta prognozuvannja - Economics and forecasting, 4, 7-35. DOI: 10.15407/eip2020.04.007. [in Ukrainian]. 